but also indicate the presence of mixed aromaticaliphatic aldehydes. An interchange may exist between these two classes of aldehydes and they may replace each other in acetal phosphatides. Striking differences in the occurrence and distribution of bound aldehyde in normal and pathological kidneys from human autopsies speak for the physiological significance of stored aldehyde ${ }^{19}$. Thus, aldehydes with antipressor and depressor effect may be conserved in this form, so that they may be mobilized for various needs of the organism. These aldehyde depots can be depleted in tissue sections by incubation with aromatic amines such as sulphanilic and para-aminobenzoic acids and may serve a similar purpose of local detoxification in vivo. They would be espeoially suitable to combat undesirable accumulations of pressor amines. Thus they may function as temporary 'buffers' delaying the onset of experimental hypertension which, in spite of the immediate production of renal ischemia, appears only three or four days after the Goldblatt operation.

The above diagram illustrates the hypothetical sequences of reactions from cyclic amino acids through pressor amines, antipressor and depressor substances to inert end-products. The equilibrium between these transformations, obtaining under physiological conditions, is disturbed in renal hypertension; the pressor amines then accumulate and at the same time their antagonists are depleted and used up. Extracts with depressor effect have been obtained from normal kidney ${ }^{20}$. In experimental unilateral renal ischemia in $\operatorname{dogs}^{21}$ the production of the antagonists in the intact kidney prevents the persistence of hypertension in spite of the continuous output of pressor amines from the ischemic kidney.

Department of Chemistry

KURT A. OsTeR*.

Laboratories of the Mount Sinai Hospital, New York. July 10.

*George Blumenthal, Jr. Fellow. Partly supported by a grant of Messrs. Winthrop Chemical Company.

${ }^{1}$ Oster, K. A., and Sorkin, S. Z., "Effects of Intravenous Injections of 1-Dopa upon Blood Pressure" (in the press)

2 Bing, R. J., Amer. J. Phys., 132, 497 (1941).

"Guggenheim, M., "Die biogenen Amine", 3rd edition (Basel, 1940).

- Arnow, L. E., J. Biol. Chem., 120, 151 (1937).

s Raper, H. S., Biochem. J., 21, 89 (1927).

- Schrocder, H. A., and Adams, M. K., J. Exp. Med., 73, 531 (1941).

'Soloway, S. O., and Oster, K. A., Proc. Soc. Exp. Biol. Med., 50, 108 (1942)

s Green, D. E., and Richter, D., Biochem. J., 31, 596 (1937).

- Oster, K. A., and Sobotkn, H., "Effect of 5,6-Diketo-tetrahydrindole Derivatives on Blood Pressure" (in preparation).

${ }^{10}$ Kisch, B., and Oppenheimer, C., "Handb. d. Biochem.", Suppl., I, 563 (1933).

11 Beyer, K. H., J. Pharm. Exp. Ther., 71, 304 (1941).

12 Hare, M. L. C., Biochem. $J ., 22,965$ (1928).

13 Bernheim, M. L. C., J. Biol. Chem., 93, 299 (1931).

${ }^{14}$ Robinson, R., J. Chem. Soc., 1079 (1930). Hahn, O., and Schales, K. Ber. Chem. Ges., 68, 24 (1935). Schopf, G., and Angew, Chem. $50,779,797(1937)$.

${ }_{15}$ Holtz, P., Heise, C., and Luedtke, C., Arch. Exp. Path. u. Pharm., $191,87(1938)$

16 Goodman, L., and Gilman, A., "The Pharmacological Basis of Therapeutics", 403 (New York, 1941).

${ }^{17}$ Feulgen, $\mathbf{R}_{\text {., }}$ and Voit, K., Pfluegers Arch., 206, 389 (1924) Feulgen, R., and Bersin, 'i'h., Z. physiol. Chem., 206, 217 (1939),

${ }^{18}$ Feulgen, R., Imhaeuser, K., and Behrens, M., Z. physiol. Chem. 180, 101 (1929).

2 Oster, K. A., Schlossmann, N. C., and Sobotka, H., "Histochemical Demonstration of Amine Oxidase: Chemical Nature of the Demonstration of Amine Oxidase Chemical Nature of the

${ }^{20}$ Harrison, F. R., Grollman, A., and Willams, J. R., jr., Amer. J. Phys., 128, 116 (1940). Page, I. H., Helmer, O. M., Kohlstaedt K. G., Fonts, P. J., Kempf, G. F., and Corcoran, A. C., Proc. Soc. Exp. Biol. and Med., 43, 722 (1940).

21 Goldblatt, H., Lynch, J., Hanzal, R. F., Summerville, W. W. J. Exp. Med., 59, 547 (1934).

29 Philpot, F. J., Biochem. J., 31, 856 (1937). Oster, K. A., Solway, S. J., J. Mount Sinai Hiosp. (in the press).

\section{Self-incompatibility in Certain Diploid Potato Species}

Pal and Puskar Nath ${ }^{1}$ have reported that the diploid $(2 n=24)$ potato species, $S$. arrac-papa, S. Caldasii, S. chacoense, S. Jamesii and S. subtilius, are self-incompatible. Under Cambridge conditions the diploid species, $S$. Rybinii, S. boyacense, S. lanci. forme and $S$. phureja, also appear to be self-incompatible.

Only one clone of $S$. Rybinii, which Salaman ${ }^{2}$ states he was unable to infect with either leaf roll or potato virus $Y$, has been brought to Europe, and on selfing this clone never sets berries. It will, how. ever, cross readily with the closely related species S. boyacense (clone E.P.C. 546), which also does not set berries on selfing. Berries containing a very large number of seeds are obtained from this cross and from the reciprocal. Also, as is shown in the table, $\dot{F}_{1}$ plants from the cross are cross-compatible with either parent. It has not, however, been possible to show that only four types of $F_{1}$ plants, such as would be expected on a simple oppositional factor hypothesis, are produced.

\begin{tabular}{|c|c|c|c|c|c|c|c|}
\hline \multirow{8}{*}{ 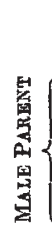 } & & \multicolumn{6}{|c|}{ FEMALE PARENT } \\
\hline & & S. Rybinii & E.P.C. 546 & $F_{14}$ & $F_{1} 6$ & $F_{1} 8$ & $F_{1} 10$ \\
\hline & S. Rybinii & - & + & + & - & + & + \\
\hline & E.P.C. 546 & + & - & & & & \\
\hline & $\left\{F_{1} 4\right.$ & + & & - & & - & \\
\hline & $\left\{F_{1} 6\right.$ & & & + & & - & + \\
\hline & $F_{1} 8$ & + & + & - & - & - & + \\
\hline & $F_{1} 10$ & + & + & & - & + & - \\
\hline
\end{tabular}

No berries have been obtained from selfing any of the clones of the blight-immune, Mexican diploid species $S$. lanciforme which was brought back by the Empire Potato Expedition as seeds. Berries containing numerous seeds have, however, been obtained from the following crosses between clones, E.P.C. $40 \cdot 3 \times 40 \cdot 4$, E.P.C. $40 \cdot 3 \times 40 \cdot 7$, E.P.C. $40 \cdot 4 \times 40 \cdot 3$, E.P.C. $40 \cdot 6 \times 40 \cdot 3$ and E.P.C. $40 \cdot 6 \times 40 \cdot 4$.

Similarly, two clones of S. phureja, E.P.C. 1307 and E.P.C. 1310, have never set berries on selfing, but berries with seeds were obtained from the cross E.P.C. 1310 female $\times$ E.P.C. 1307.

G. P. Carson.

School of Agriculture,

H. W. Howard.

Cambridge.

Aug. 16.

I Pal, B. P., and Puskar Nath, NATURE, 149, 246 (1942).

Salaman, R. N., Indian J. Agric. Sci., 8, 119 (1938).

\section{Effect of Sulphanilamides on the Growth of Micro-organisms in Presence and Absence of $p$-Aminobenzoic Acid}

LAsT year I presented some results of experiments on the antagonism between $p$-aminobenzoic acid and sulphanilamides (sulphanilamide, sulphapyridine and sulphathiazole) in autotrophic organisms ${ }^{1}$. These experiments were carried out with two strains of the freshwater diatom Nitzschia palea var. debilis (Kg.) Grun. I also made experiments on the inhibitory action of sulphanilamide on the growth of $N$. communis Rabenhorst, N. Kützingiana var. exilis Grun. (f. multiplex $^{2}$ ) and further strains of $N$. palea var. debilis. 